\title{
Temporal and Spatial Distribution and Fluorescence Spectra of Dissolved Organic Matter in Plateau Lakes - A Case Study of Qinghai Lake
}

\section{Zheng Li}

Chinese Research Academy of Environmental Sciences

\section{Zhenghui Fu}

Chinese Research Academy of Environmental Sciences

\section{Yang Zhang}

Peking University

\section{Yunyan Guo}

Chinese Research Academy of Environmental Sciences

\section{Feifei Che}

Chinese Research Academy of Environmental Sciences

\section{Huaicheng Guo}

Peking University

\section{Shuhang Wang (D 449089320@qq.com)}

Chinese Research Academy of Environmental Sciences

\section{Research Article}

Keywords: Dissolved organic matter (DOM), Colored dissolved organic matter (CDOM), Qinghai Lake, Water Quality, Temporal and spatial distribution

Posted Date: November 30th, 2021

DOI: https://doi.org/10.21203/rs.3.rs-1084038/v1

License: @ (i) This work is licensed under a Creative Commons Attribution 4.0 International License. Read Full License

Version of Record: A version of this preprint was published at Water on December 7th, 2021. See the published version at https://doi.org/10.3390/w13243481. 


\section{Abstract}

Dissolved organic matter (DOM) has a great influence on the main pollution indexes of lakes (such as COD). Therefore, DOM research is the basis for understanding the water environmental quality and the law of pollutant migration and transformation in the basin. In this study, the water quality monitoring data of Qinghai Lake water body and 8 rivers around the lake from 2010 to 2020 were collected, and the dissolved organic matter (DOM) was synchronously sampled in May, September and October 2020. The optical characteristics of DOM, the temporal and spatial distribution of CDOM and the fluorescence spectrum and fluorescence component characteristics of FDOM were analyzed and studied. The results show that: (1) From 2010 to 2020 , the annual mean value of $C O D_{C r}$ of Qinghai Lake water body fluctuates in the range of Class III to Class $\mathrm{V}$ according to the environmental quality standard of the surface water, and shows a downward trend first and then an upward one. In general, the mean value of $\mathrm{COD}_{\mathrm{Cr}}$ concentration in Qinghai Lake water body is at a high level and varies slightly among different months. (2) The mean value of $\mathrm{COD}_{\mathrm{Cr}}$ concentration of the eight main rivers entering Qinghai Lake from 2010 to 2020 can be sorted from lowest to highest as follows: Ganzi River, Buha River, Jilmeng River, Hargai River, Shaliu River, Quanji River, HeMa River, and DaoTang River. (3) The concentration of CDOM in Qinghai Lake shows not only obvious seasonal variation (October, September and May, in the descending order) but also spatial variation. (4) The three-dimensional fluorescence spectrum matrix data of DOM in Qinghai Lake were analyzed by PARAFAC model, and four DOM fluorescence components with single maximum emission wavelength were analyzed.

\section{Introduction}

Dissolved organic matter (DOM) is ubiquitous in soil, rivers, lakes and oceans in nature. It is an important organic component in water (Fig. 1) (Battin et al., 2009). DOM is a complex organic mixture composed of different functional groups and molecular structures (Rizzuto et al., 2021), which usually includes humus, carbohydrates and proteins, and it plays an important role in the global carbon cycle (Xiao et al., 2019). In natural water bodies, DOM may be derived from the decomposition of plant substances and extracellular substances released by aquatic organisms by microorganisms, or the transportation of degraded organic substances from the surrounding terrestrial environment by rivers and groundwater (Song et al., 2019; Wang et al., 2019).

(DOC is dissolved organic carbon; CDOM is colored dissolved organic matter; FDOM is fluorescent dissolved organic matter; DBC is dissolved black carbon.)

CDOM is the main light absorbing substance in dissolved organic matter (DOM) in natural water, which can affect the migration and transformation of heavy metals and organic pollutants (Patidar et al., 2015). The part with fluorescence characteristics in CDOM is called fluorescent dissolved organic matter (FDOM), which is of great significance to aquatic ecosystems (Mostofa et al., 2013). As an important part of DOM, its important role in natural water environment has long been concerned. At present, ultraviolet, visible and fluorescence spectra are mainly used to study CDOM of water bodies from different sources 
at home and abroad. Foreign studies on CDOM have been carried out earlier, and the research fields include CDOM origin, destination, distribution, migration and transformation, and spatio-temporal changes. The Tibet Plateau is the highest plateau on earth and has always enjoyed the reputation of "Asian water tower" and "third pole". Its high terrain and unique geographical location have a significant impact on the global climate (Yang., 2009; Wang et al., 2003). Qinghai Lake is an important water body to maintain the ecological security of the Tibet Plateau. It plays a great role in improving and regulating climate and promoting a virtuous cycle of Regional Ecology (Xinhua news agency., 2020). However, there are few investigations or regional environmental studies on the water environment of Qinghai Lake Basin. In recent years, with the acceleration of urbanization and the rapid development of tourism, Qinghai Lake Basin is facing great ecological pressure. Therefore, the investigation on the water quality of Qinghai Lake and the study on the temporal and spatial distribution and optical characteristics of dissolved organic matter in the water body are helpful to deeply understand the current situation of the water environment of Qinghai Lake, the carbon cycle process within the basin and its potential impact on water quality, and can provide background data support for lake water environment analysis and water body assessment.

\section{Methodology}

\section{Study area}

Qinghai Lake is located in the northeast of Qinghai Tibet plateau at the junction of Gangcha County, Gonghe County and Haiyan County. It is the largest inland salt water lake in China. In 2019, the lake area reached $4519 \mathrm{~km}^{2}$. The lake water is weakly alkaline, low oxygen content and salt content is $14.1 \mathrm{G} \mathbb{\mathrm { L }} \mathrm{L}^{-1}$, transparency below 3M. Qinghai Lake Basin is between $97^{\circ} 50^{\prime} \sim 101^{\circ} 20^{\prime}$ E and $36^{\circ} 15^{\prime} \sim 38^{\circ} 20^{\prime} \mathrm{N}$, with a drainage area of about $29661 \mathrm{~km}^{2}$ (Yu et al., 2021). The overall outline is oval, and the terrain is high in the northwest and low in the northeast. It is located at the intersection of the East Asian monsoon, the northwest arid region and the alpine region of the Qinghai Tibet Plateau. It belongs to the semi-arid and alpine climate of the plateau, and the precipitation is unevenly distributed throughout the year(Yu et al., 2021). Qinghai Lake is located in the southeast of the basin and is mainly supplied by rivers and precipitation. Most of the rivers entering the lake are seasonal rivers and concentrated in the West and north of the lake. The main supply rivers are Buha River, Shaliu River, Quanji River, hargai River, Ganzi River and HeMa river.

In this study, Qinghai Lake Basin is taken as the research object, 14 sampling points are set, and the layout of sampling points is shown in Figure 2-1. In May, September and October 2020, Qinghai Lake Basin was comprehensively sampled three times, and $2.5 \mathrm{~L}$ surface water samples $(0 \sim 0.25 \mathrm{~m}$ from the water surface) were collected, stored in brown glass bottles (constant $4^{\circ} \mathrm{C}$ ) and sent back to the laboratory for testing.

\section{Sample Method}


Seawater samples are collected by Niskin water collector, and the parameters such as water depth, temperature and salinity are measured synchronously by CTD sensor during seawater collection. The river water samples are taken manually, and the parameters such as temperature, salinity and $\mathrm{pH}$ value of the on-site river water are synchronously measured in the river by the portable water quality analyzer. Dom and CDOM use filtering devices to filter the water samples to be collected in the shortest possible time, and the filtered samples can be frozen and stored. Thaw in the laboratory before measurement, and transfer sufficient samples to doc measurement sample bottle $(24 \mathrm{ml}$ or $40 \mathrm{ml})$ with burned Pasteur glass pipette (Corning). If the sample cannot be measured immediately, add acid to the sample $(\mathrm{pH}<2)$ and store it in cold storage for measurement.

\section{Sample Analysis}

In order to facilitate the examination of the instruments used in the experiment and the experimental process, the instruments used for parameter determination correspond to Table 1, and the process corresponds to the back.

Table 1

instrument used for parameter determination.

\begin{tabular}{|c|c|c|c|}
\hline Measurement index & Instrument / method & Model & $\begin{array}{l}\text { Origin / } \\
\text { manufacturer }\end{array}$ \\
\hline $\begin{array}{l}\text { Water temperature }(\mathrm{T}), \mathrm{pH} \text {, and } \\
\text { dissolved oxygen (DO) }\end{array}$ & $\begin{array}{l}\text { Multi parameter water } \\
\text { quality monitor }\end{array}$ & $\begin{array}{l}\text { YSI } \\
6600 \mathrm{~V} 2\end{array}$ & USA \\
\hline $\begin{array}{l}\text { potassium bichromate }\left(\mathrm{COD}_{\mathrm{Cr}}\right) \text { and } \\
\text { permanganate }\left(\mathrm{COD}_{\mathrm{Mn}}\right)\end{array}$ & Titrimetric method & $\begin{array}{l}\text { (MEP of } \\
\text { PRC 1989) }\end{array}$ & China \\
\hline TOC(DOM) & $\begin{array}{l}\text { Total organic carbon } \\
\text { analyzer }\end{array}$ & TOC-V & $\begin{array}{l}\text { Shimadzu, } \\
\text { Kyoto, Japan }\end{array}$ \\
\hline CDOM & $\begin{array}{l}\text { (UV-Vis) Ultraviolet visible } \\
\text { spectrophotometer }\end{array}$ & UV-2600PC & $\begin{array}{l}\text { Shimadzu, } \\
\text { Kyoto, Japan }\end{array}$ \\
\hline FDOM & Fluorescence spectrum & $\begin{array}{l}\text { Hitachi F- } \\
7000\end{array}$ & $\begin{array}{l}\text { Hitachi, Tokyo, } \\
\text { Japan }\end{array}$ \\
\hline
\end{tabular}

DOM and CDOM before analysis, the water samples were filtered using pre-combusted $\left(450^{\circ} \mathrm{C}\right.$ for $\left.5 \mathrm{~h}\right)$ glass fiber filters $(0.7 \mu \mathrm{m}, \mathrm{GF} / \mathrm{F}$, Whatman).

The absorption coefficient of CDOM at $254 \mathrm{~nm}\left(\mathrm{a} 254, \mathrm{~m}^{-1}\right)$ was used as a proxy for CDOM concentration. The value of a254 was calculated by the following equation (Song et al. 2019): a254 1/4 2:303A254=L $\partial 1 \mathrm{P}$ where $A 254$ is the absorbance at $254 \mathrm{~nm}$ and $\mathrm{L}$ is the path length of the cuvette $(0.1 \mathrm{~m})$. Fluorescence EEMs-PARAFAC analysis Fluorescent DOM (FDOM) with a $150 \mathrm{~W}$ Xe lamp as the excitation light source and a 9PMT voltage of $700 \mathrm{~V}$. The excitation wavelength (Ex) and emission wavelength (Em) scanning range were from 200 to $450 \mathrm{~nm}$ and 250 to $600 \mathrm{~nm}$, respectively. The increments of excitation and emission wavelength were all set to $2 \mathrm{~nm}$. The slit width and the scanning speed were set as $10 \mathrm{~nm}$ and 
$12,000 \mathrm{~nm} \cdot \mathrm{min}^{-1}$, respectively. In order to reduce the influence of instrument conditions and Raman scattering on fluorescence spectra, the ultrapure water blank was used as a reference. Before PARAFAC analysis, the EEM fluorescence data should be preprocessed as the method used by Wang et al. (2018). PARAFAC modeling was performed using MATLAB (The MathWorks, Natick, MA, USA) with the DOM Fluor toolbox. The number of components was determined based on a core consistency test and splithalf validation. The fluorescence index $(\mathrm{FI})$ is the fluorescence intensity ratio of the fluorescence emission spectrum at 450 and $500 \mathrm{~nm}$ with an excitation light wavelength of $370 \mathrm{~nm}$ (McKnight et al.2001; Stedmon and Bro 2008; Stedmon and Bro 2008).

\section{Results And Discussion}

\section{Time variation of $\mathrm{COD}_{\mathrm{cr}}$ and permanganate index in Qinghai Lake from 2010 to 2020}

In order to make clear of the background values of the Qinghai Lake watershed, the monitoring water quality indexes were collected and analyzed to conclude the characterizations of the water quality variations. According to the historical monitoring data of water quality (Fig. 3-1), the $\mathrm{COD}_{\mathrm{cr}}$ concentration in Qinghai Lake was between 18.11 and $38.00 \mathrm{mg} / \mathrm{L}$ from 2010 to 2020, with an average of $27.10 \mathrm{mg} / \mathrm{L}$, which was at the surface class IV level. Except for the large fluctuation of $\mathrm{COD}_{\mathrm{Cr}}$ concentration in 2010 and 2011, the fluctuation of CODCr concentration in Qinghai lake water in other years is relatively small. From the mean value of CODCr at each historical monitoring point, the mean value of $\mathrm{COD}_{\mathrm{Cr}}$ at Sha Dao point is relatively the highest, $43.84 \mathrm{mg} / \mathrm{L}$.

From 2010 to 2020, the annual mean value of CODcr of Qinghai lake water body first decreased and then increased, and fluctuated greatly, fluctuating between class III V levels of surface water. Among them, the average value of $C O D_{C} r$ in 2011 is relatively the highest, close to the upper limit of class $V$ water quality standard for surface water, and the annual average value of CODCr in 2012 is relatively the lowest; In 2020, CODcr will rise to class IV water level, with an average of $36.02 \mathrm{mg} / \mathrm{L}$.

The on-site monitoring in May, September and October 2020 shows that (Fig. 3-2) the annual CODcr of Qinghai lake water body ranges from 31 to $48 \mathrm{mg} / \mathrm{L}$, with an average of $39.21 \mathrm{mg} / \mathrm{L}$. The CODcr of all point water bodies exceeds the class IV standard of surface water (threshold $\leq 30 \mathrm{mg} / \mathrm{L}$ ), and the CODcr of some point water bodies exceeds the class $V$ standard of surface water (threshold $\leq 40 \mathrm{mg} / \mathrm{L}$ ). From the perspective of monthly variation, the range of CODCr in Qinghai lake water body is $31 \sim 45 \mathrm{mg} / \mathrm{L}$, $32 \sim 47 \mathrm{mg} / \mathrm{L}$ and $31 \sim 48 \mathrm{mg} / \mathrm{L}$ respectively, and the average values are $40.13 \mathrm{mg} / \mathrm{L}, 39.43 \mathrm{mg} / \mathrm{L}$ and $38.09 \mathrm{mg} / \mathrm{L}$. on the whole, the difference of $\mathrm{COD}_{\mathrm{Cr}}$ in Qinghai lake water body in different months is small, and the CODcr concentration is at a high level. Qinghai Lake is a large salt water lake in Western China. The population in the basin is rare. Its CODcr is mainly affected by rivers entering the lake, grassland nonpoint sources and surrounding human activities. 
According to the historical monitoring data( Fig. 3-3), the permanganate index concentration of Qinghai lake water from 2010 to 2020 is between 2.14 and $5.53 \mathrm{mg} / \mathrm{L}$, with an average of $3.89 \mathrm{mg} / \mathrm{L}$, which is at the surface class II level. Except for the large fluctuation of permanganate index concentration in water body in 2012, the fluctuation of permanganate index concentration in Qinghai lake water body in other years is relatively small. From the mean value of permanganate index at each historical monitoring point, the mean value of permanganate index at Shadao point is relatively the highest, which is $5.39 \mathrm{mg} / \mathrm{L}$.

From 2010 to 2015, the annual mean value of permanganate index of Qinghai lake water body fluctuated as a whole, but all met the class III level of surface water. From 2016 to 2020, the annual average value of permanganate index of Qinghai lake water body showed a downward trend and was basically at the class II level of surface water. Among them, the permanganate index remained at the level of $2.14 \sim 2.35$ $\mathrm{mg} / \mathrm{L}$ from 2018 to 2020, slightly higher than the class I water quality limit. In recent years, the average value of permanganate index in 2011 is relatively the highest, which is $5.53 \mathrm{mg} / \mathrm{L}$, close to the upper limit of class III water quality standard for surface water, and the average annual value of permanganate index in 2019 is relatively the lowest.

\section{Time variation of CODcr and permanganate index of rivers entering Qinghai Lake from 2010 to 2020}

From 2010 to 2020, CODcr of main rivers entering Qinghai Lake Basin was 7.50 13.94 mg/L, with an average of $10.99 \mathrm{mg} / \mathrm{L}$; The CODcr of rivers entering the lake is lower than that of lakes as a whole( Fig. 4-1).

Except for the DaoTang River, the mean value of CODcr of major rivers is relatively similar from 2010 to 2020 , and the interannual variation trend is relatively consistent. The average CODcr of the eight main rivers entering Qinghai Lake from 2010 to 2020 shows the law of Ganzi River < Buha River < jilmeng River $<$ hargai River < Shaliu River < Quanji River < HeMa River < DaoTang river.

From 2010 to 2020, the permanganate index of main rivers entering the lake in Qinghai Lake Basin was $1.44 \sim 2.98 \mathrm{mg} / \mathrm{L}$, with an average of $2.18 \mathrm{mg} / \mathrm{L}$ ( Fig. 4-2); The permanganate index of rivers entering the lake is lower than that of lakes as a whole.

Except for Daotang River and Heima River, the mean value of permanganate index of main rivers is relatively similar from 2010 to 2020, and the interannual variation trend is relatively consistent. The average value of permanganate index of the eight main rivers entering Qinghai Lake from 2010 to 2020 shows the law of Buha River < Shaliu River < hargai River < jilmeng River < Ganzi River < Quanji River < Heima River $<$ DaoTang river. Except Shaliu River and Ganzi River, the law of other rivers is consistent with CODcr.

\section{Spatial distribution of $\mathrm{COD}_{\mathrm{cr}}$ and permanganate index in Qinghai Lake}


There are obvious differences in the spatial distribution of $\mathrm{COD}_{\mathrm{Cr}}$ concentration in Qinghai Lake( Fig. 4-3). In May, $C O D_{C r}$ in the East is higher than that in the west, and that in the center of the lake is higher than that in the coast; In September and October, CODcr of water body showed two high areas, namely, near Jiangxi ditch wharf and Sand Island, Jiangxi ditch wharf and Qinghai Lake fishing ground wharf. From the perspective of spatial distribution characteristics, the higher values in the three months are mainly concentrated in Jiangxi ditch wharf and Qinghai Lake fishery wharf. Jiangxi ditch wharf and Qinghai Lake fishery wharf are located in the south of Qinghai Province, and the planting industry along the south coast is mainly. Therefore, the input of external sources leads to the higher concentration of CODCr in the water body in the south of Qinghai Lake than in other regions.

There are obvious differences in the spatial distribution of permanganate index concentration in Qinghai Lake( Fig. 4-4). In May, the permanganate index concentration range is $1.80 \sim 4.50 \mathrm{mg} / \mathrm{L}$, with an average of $2.21 \mathrm{mg} / \mathrm{L}$, in September, the permanganate index concentration range is $1.90 \sim 14.50 \mathrm{mg} / \mathrm{L}$, with an average of $2.83 \mathrm{mg} / \mathrm{L}$, and in October, the permanganate index concentration range is $1.80 \sim 4.50 \mathrm{mg} / \mathrm{L}$, with an average of $2.29 \mathrm{mg} / \mathrm{L}$. In May and September, the permanganate index in the East was higher than that in the West; In October, the permanganate index of water body showed three high areas, namely the center of the lake, the East and the west, and the shore area close to the center of the lake. From the perspective of spatial distribution characteristics, except for the center of the lake in October, the highvalue areas appear in the areas close to the shore. Therefore, the external input may be the reason for the higher concentration of permanganate index in the water body of Qinghai Lake than in other areas.

\section{Optical Properties Of Dom In Qinghai Lake}

Colored soluble organic matter (CDOM) and fluorescent soluble organic matter (FDOM) are two important indicators of optical properties in DOM. CDOM is a component of DOM that can absorb ultraviolet and photosynthetic effective radiation; FDOM is a DOM component that can release fluorescent photons after absorbing light radiation. Therefore, CDOM and FDOM are commonly used to characterize the optical characteristics of DOM.

(1) Seasonal and spatial distribution of CDOM

The concentration of CDOM is characterized by its absorption coefficient a254 at $254 \mathrm{~nm}$. The field monitoring data in May, September and October 2020 show that (Fig. 5-1)the value of a254 in Qinghai lake water body is between 8.80 13.29 $\mathrm{M}^{-1}$, with obvious seasonal differences. Among them, a254 in water in May is between $8.80 \sim 9.83 \mathrm{M}^{-1}$, with an average value of $9.17^{\mathrm{M}-1}$, which is significantly lower than that in other seasons $(P<0.01)$; In September, a254 in the water body was between $8.73 \sim 10.64 \mathrm{M}^{-1}$, with an average value of $9.48 \mathrm{M}^{-1}$; In October, a254 in the water body is between 9.14 13.29 $\mathrm{M}^{-1}$, with an average value of $9.81 \mathrm{M}^{-1}$, showing the law of October>September>May. The concentration of CDOM in Qinghai Lake not only has obvious seasonal differences, but also shows different spatial differences. Among them, the highest value of CDOM at each sampling point in the water body in May, September 
and October appeared near erlangjian in the south of the lake. In addition, the value of CDOM in the water body on the West Bank of Qinghai Lake in May was also high.

(2) Fluorescence spectrum and fluorescence component characteristics of FDOM

The three-dimensional fluorescence spectrum matrix data of DOM in Qinghai Lake were analyzed by PARAFAC model, and four DOM fluorescence components with single maximum emission wavelength were analyzed. The maximum excitation / emission wavelength distribution of the four fluorescent components and the three-dimensional fluorescence spectra of the principal components are shown in the figure below( Fig. 5-2).

The excitation wavelength of component $\mathrm{C} 1$ is at $242 \mathrm{~nm}$ and the maximum emission wavelength is near $422 \mathrm{~nm}$, which reflects the land-based high molecular weight humic acid, mainly from the degradation of higher plants or soil leaching; Component $\mathrm{C} 2$ has two obvious excitation wavelengths at $220 \mathrm{~nm}$ and 272 $\mathrm{nm}$, and the maximum emission wavelength is $422 \mathrm{~nm}$, which reflects the low molecular weight fulvic acid like fluorescence peak, which mainly comes from the fluorescence peak formed by biodegradable organic compounds; Component C3 has two obvious excitation wavelengths at 232 and $286 \mathrm{~nm}$, and the maximum emission wavelength is $338 \mathrm{~nm}$. It belongs to the binding peak of protein like and fulvic acid like, which has a red shift compared with the conventional tryptophan like peak; Component C4 has an obvious excitation wavelength at $270 \mathrm{~nm}$ and the maximum emission wavelength is $478 \mathrm{~nm}$, reflecting the fluorescence peak formed by polymer humic acid.

Overall, the proportion of each component in the total fluorescence intensity of FDOM in May and September is $\mathrm{C} 2>\mathrm{C} 1>\mathrm{C} 4>\mathrm{C} 3$, and the proportion of each component in the total fluorescence intensity of FDOM in October is $\mathrm{C} 3>\mathrm{C} 2>\mathrm{C} 1>\mathrm{C} 4$, which has certain seasonal differences( Fig. 5-3).

In the three sampling surveys of Qinghai Lake in May, September and October(Fig. 5-4), the average total fluorescence intensity of FDOM in the water body of Qinghai Lake was 22.20, 24.17 and 42.80 R.U., showing a significant seasonal difference law of October>September>May. The spatial distribution of the total fluorescence intensity of FDOM in water is also different in different seasons. The spatial difference in October is more obvious than that in May and September. However, in the three surveys, the highest value of the total fluorescence intensity of FDOM in water appears near erlangjian in the south of Qinghai Province.

The mean values of C1 components in the overlying water of Qinghai Lake in May, September and October are 5.85, 6.86 and 7.23 R.U. (Fig. 5-5), showing the law of October>September>May. The spatial distribution characteristics are similar to the total amount, and the spatial difference is obvious. The highest value appears near erlangjian in the south of Qinghai and the lowest value appears in the center of the lake.

The mean values of C2 components in the water body of Qinghai Lake in May, September and October were $6.93,6.96$ and 9.93 R.U. (Fig. 5-6), showing the law of October>September>May. The spatial 
distribution characteristics are similar to the total amount, and the spatial difference is obvious. The highest values in May and October appear in the south of Qinghai, and the highest values in September appear in the southwest of the lake.

The mean values of C3 components in the water body of Qinghai Lake in May, September and October were 4.59, 4.96 and 20.28 R.U. (Fig. 5-7), showing the law of October>September>May. The spatial distribution characteristics are similar to the total amount, and the spatial difference is obvious. The highest values appear near erlangjian in the south of Qinghai and Hunan.

The mean values of C4 components in the water body of Qinghai Lake in May, September and October were 4.82, 5.39 and 5.36 R.U. (Fig.5-8) respectively, showing a different law from other components, that is, September>0ctober>May. The spatial distribution characteristics are similar to the total amount, and the spatial difference is obvious. The highest values appear near erlangjian in the south of Qinghai and Hunan.

Figure 5-8 spatial distribution characteristics of C4 fluorescence intensity in Qinghai lake water in different seasons

\section{Bioavailability Of Dom In Qinghai Lake}

Both COD and BOD5 are used to quantitatively reflect the degree of organic pollution in water. Previous studies have shown that when BOD5 / CODcr $\geq 30 \%$, it is biodegradable sewage; If $\mathrm{BOD}_{5} / \mathrm{COD} c r<30 \%$, it is difficult to biodegrade sewage. In this study(Fig. 6), the $\mathrm{BOD}_{5}$ / CODcr value of Qinghai Lake is between $1.90 \% \sim 5.29 \%$, with an average of $3.36 \%$, which is obviously low, indicating that the bioavailability of organic matter in Qinghai Lake is poor and difficult to decompose. This non decomposable organic matter will continue to accumulate into the sediment over time and migrate between water and sediment under the disturbance of wind, waves and fish, which also reflects the reason for the high COD of Qinghai Lake from another aspect.

\section{Conclusions}

The monitoring data from 2010 to 2020 showed the high $\mathrm{COD}_{\mathrm{Cr}}$ values and the high $\mathrm{COD}_{\mathrm{Mn}}$ and BOD values in the Qinghai Lake. From 2010 to 2020, the annual mean value of $\mathrm{COD}_{\mathrm{Cr}}$ of Qinghai lake water body first decreased and then increased, and fluctuated greatly, fluctuating between class III V levels of surface water. Spatially, the $\mathrm{COD}_{\mathrm{Cr}}$ mean value of sand island is relatively the highest, which is 43.84 $\mathrm{mg} / \mathrm{L}$. In terms of time nodes, the average value of $\mathrm{COD}_{\mathrm{Cr}}$ in 2011 is relatively the highest, close to the upper limit of class $V$ water quality standard for surface water, and the annual average value of $C O D_{C r}$ in 2012 is relatively the lowest; In $2020, C_{C O}$ will rise to class IV water level, with an average of 36.02 $\mathrm{mg} / \mathrm{L}$. From 2010 to 2015, the annual mean value of permanganate index of water body in Qinghai Lake fluctuated as a whole, but they all met the class III level of surface water. It is noteworthy that the mean value of permanganate index at Sand Island is relatively the highest, which is $5.39 \mathrm{mg} / \mathrm{L}$. From 2016 to 
2020, the average annual value of permanganate index of Qinghai lake water showed a downward trend and was basically at the level of class II surface water. Among them, the permanganate index remained at the level of 2.14 $2.35 \mathrm{mg} / \mathrm{L}$ from 2018 to 2020, slightly higher than the class I water quality limit. In recent years, the average value of permanganate index in 2011 is relatively the highest, which is 5.53 $\mathrm{mg} / \mathrm{L}$, close to the upper limit of class III water quality standard for surface water, and the average annual value of permanganate index in 2019 is relatively the lowest. The average CODcr of the eight main rivers entering Qinghai Lake from 2010 to 2020 shows the law of Ganzi River <Buha River <jilmeng River $<$ hargai River <Shaliu River <Quanji River <HeMa River <DaoTang river(3) The concentration of CDOM in Qinghai Lake not only has obvious seasonal differences (showing the law of October>September>May), but also shows different spatial differences. The three-dimensional fluorescence spectrum matrix data of DOM in Qinghai Lake were analyzed by PARAFAC model, and four DOM fluorescence components with single maximum emission wavelength were analyzed. Component $\mathrm{C} 1$ reflects terrestrial high molecular weight humic acid, which mainly comes from the degradation of higher plants or the leaching of soil; Component $\mathrm{C} 2$ reflects the low molecular weight fulvic acid like fluorescence peak, which mainly comes from the fluorescence peak formed by biodegradable organic compounds; Component $\mathrm{C} 3$ belongs to the protein like and fulvic acid like binding peak, which has a red shift compared with the conventional tryptophan like peak; Component C4 reflects the fluorescence peak formed by polymer humic acid.

\section{References}

1. Battin, T. J. et al. The boundless carbon cycle [J]. Nat. Geosci, 2 (9), 598-600 (2009).

2. Brailsford, F. L. et al. Nutrient enrichment induces a shift in dissolved organic carbon (DOC) metabolism in oligotrophic freshwater sediments[J].Science of the Total Environment, 2019(690):1131-1139

3. C.Biogeochemistry of Marine Dissolved Organic Matter. Boston, MA:Academic Press

4. change on the ecosystem services value in. the Qinghai Lake area [J]. Progress in Geography, 31 (12), 1747-1754 (2012).

5. Chen, Q. \& Li, Q. J. Discussion on difference between three assessments of water resources in Qinghai Province [J]. Journal of China Hydrology, 39 (4), 57-62 (2019).

6. Dai, S. et al. Impacts of extreme climatic events under the context of climate warming on hydrology and water resources in the Qinghai Qilian Mountains [J]. Journal of Glaciology and Geocryology, 41 (5), 1053-1066 (2019).

7. Du, J. N. et al. Hydrological characteristic of Qinghai Lake, 1956-2017 [J]. Journal of Hydroecology, 41 (4), 27-33 (2020).

8. Fang Kaikai, H. et al. Characteristics, spatial distribution and source analysis of CDOM absorption spectrum of Zhoucun reservoir in Huaihe River Basin in summer [J]. Lake Science, 29 (1), 151-159 (2017).

9. Feng Kexin, L. et al. Spatial distribution characteristics and source analysis of colored soluble organic matter in surface sediments of Danjiangkou reservoir [J]. Environmental chemistry, 35 (2), 
373-382 (2016).

10. Fu Dandan, Z., Liyan, L. \& Zhilin Review of CDOM remote sensing inversion in water [J]. Journal of Capital Normal University (NATURAL SCIENCE EDITION), 38 (2), 84-90 (2017).

11. Hedges, J. I. 2002.Why Dissolved Organics Matter [M]//Da H, Ca

12. Helms, J. R. et al. 2013.Photochemical bleaching of oceanic dissolved organic matter and its effect on

13. Huguet, A. et al. (2009) Properties of fluorescent dissolved organic matter in the Gironde Estuary. Org Geochem40:706-719

14. Lei, Y. Z. et al. Hydrological process tracing study of the alpine inland basin of the Tibetan Plateau based on hydrogen and oxygen stable isotopes and hydrochemistry [J]. Geographical Research, 40 (5), 1239-1252 (2021).

15. Li, H. M. et al. Quantitative analysis of the impacts of climate and socio-economic driving factors of land use

16. Li, S. H. et al. Correlation among evaluation indexes of river ecosystem in Qinghai Lake Basin [J]. Bulletin of Soil and Water conservation, 36 (5), 278-282 (2016).

17. Liang Jian, J. et al. Spectral characteristics and source discrimination of dissolved organic matter (DOM) in summer and winter rainfall [J]. Environmental science, 36 (3), 888-897 (2015).

18. McKnight, D. M. et al. (2001) Spectrofluorometric characterization of dissolved organic matter for indication of precursor organic material and aromaticity.Limnol Oceanogr46:38-48

19. MEP of PRC (Ministry of Environmental Protection of the People's Republic of China). Water qualitydetermination of permanganate index (China Environmental Science Press, 1989).

20. Mostofa, K. M. G. et al. Photobiogeochemistry of organic matter [M] (Springer, Berlin Heidelberg, 2013).

21. Patidar, S. K. et al. Dominance of cyanobacterial and cryptophytic assemblage correlated to CDOM at heavy metal contami-nation sites of Gujarat, India [J]. Environmental Monitoring and Assessment, 187 (1), 1-9 (2015).

22. Rizzuto, S. et al. Critical assessment of an equilibrium-based method to study the binding of waterborne organic contaminants to natural dissolved organic matter (DOM) [J].Chemosphere, 2021,285, doi:10.1016/j.chemosphere.2021.131524.

23. Song, F. et al. Depth-dependent variations of dissolved organic matter composition and humification in a plateau lake using fluorescence spectroscopy [J]., 225, 507-516 (2019).

24. Song, K. et al. (2019)Characterization of CDOM in saline and freshwater lakes across China using spectroscopic analysis.Water Res150:403-417

25. Stedmon, C. A. \& Bro, R. (2008) Characterizing dissolved organic matter fluorescence with parallel factor analysis: a tutorial.Limnol Oceanogr Methods6:572-579

26. Sun Yongliang, L., Xiaoyan, T. \& Jia, X. Heye. Climate change and hydrological effects in Qinghai Lake Basin [J].Resource science, 2008 (03):354-362(in chinese) 
27. Wang, D., Liu Chang, L., Meng \& Jingmei sun Degradation of dissolved organic matter in sediment by sludge containing humic acid reducing bacteria [J]. Environmental engineering, 2019, 37 (6): 150154(in chinese)

28. Wang, W. et al. (2018) Differences in fluorescence characteristics and bioavailability of water-soluble organic matter (WSOM) in sediments and suspended solids in Lihu Lake, China.Environ Sci Pollut Res Int25:12648-12662

29. WANG et al. ZHOUXiao-lan,NI Shao-xiang,Analysis on climate change in the region ofQinghai lake in the past40 years[J].Journal of Nanjing Institute of Meteorology, 2003, 26(2): 228ī1/2ž235.(in chinese)

30. Xiao, Y., Li, W. \& Yang, S. Hydrodynamic-sediment transport response to waterway depth in the Three Gorges Reservoir, China [J].Arabian Journal of Geosciences, 2021, 14(9), doi:10.1007/s12517-02107090-7.

31. Yang Ping. Climate change and hydrological effects of Qinghai Lake since the little ice age [D].Lanzhou University, 2009(in chinese)

32. Yu et al. "Analysis of sources and characteristics of colored soluble organic matter in Qinghai Lake Basin." Environmental Science.(2021) doi:10.13227/j.hjkx.202105164. (in chinese)

\section{Figures}




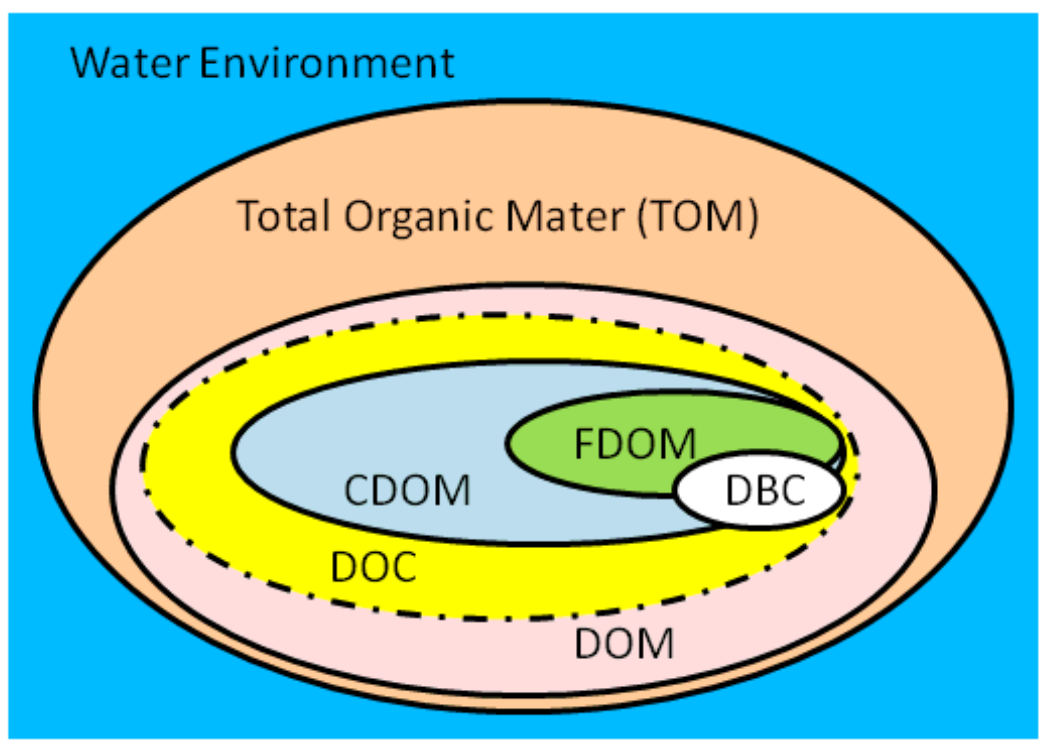

Figure 1

Schematic diagram of main organic components in natural water 


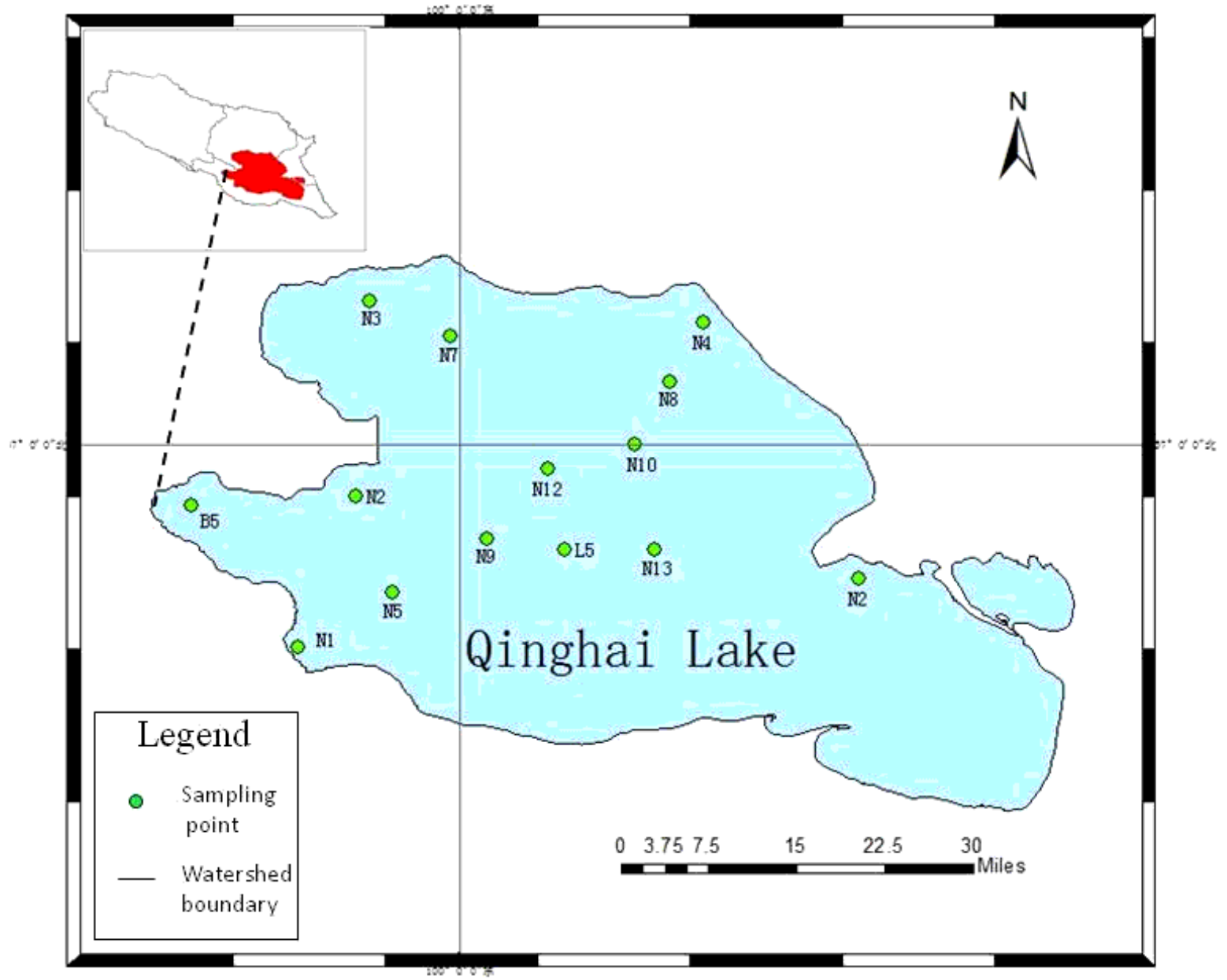

Figure 2

location of DOM sampling points in Qinghai Lake 

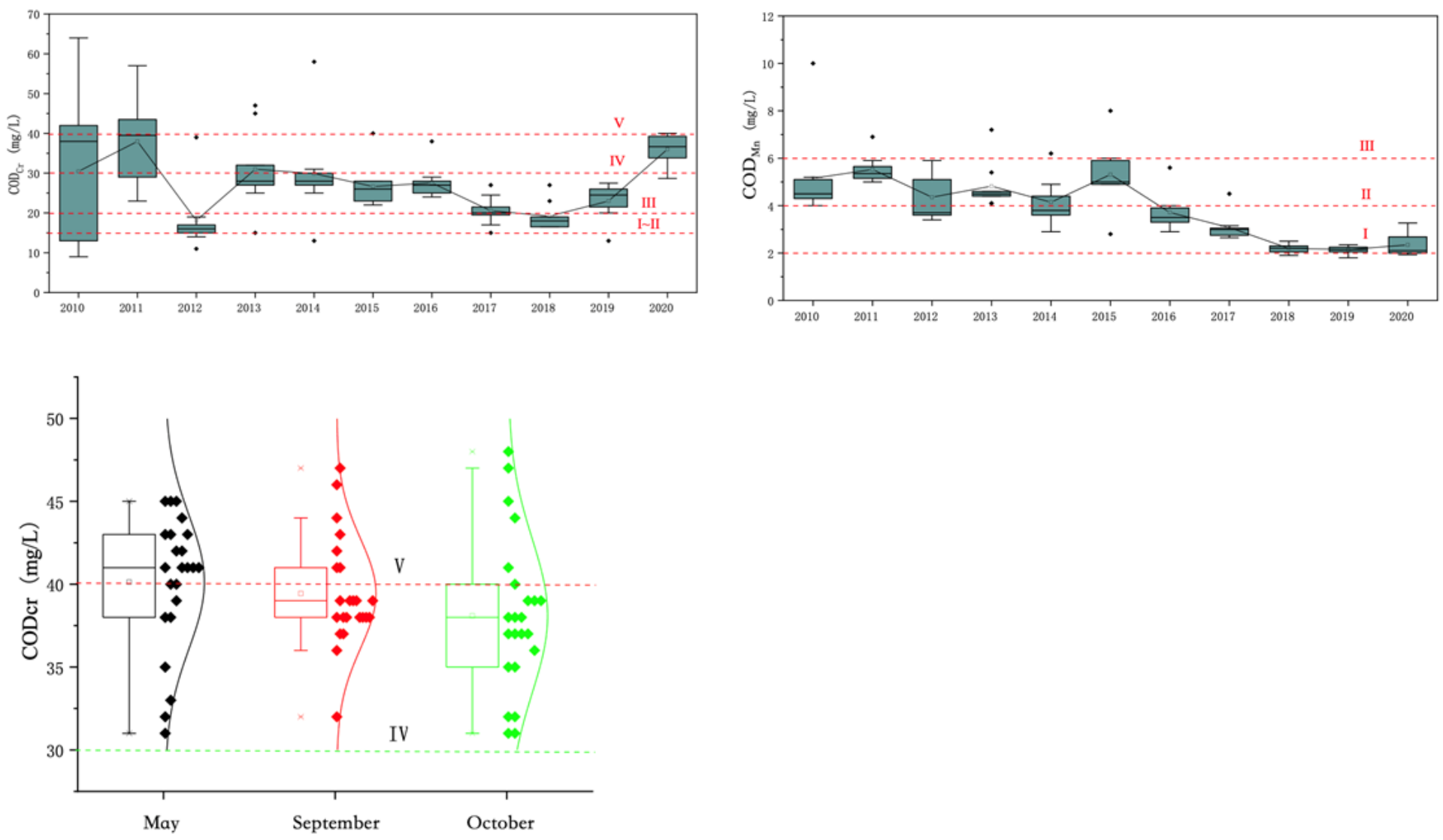

Figure 3

change trend of CODCr in Qinghai Lake from 2010 to 2020 characteristics of CODCr value in Qinghai lake water body in different seasons change trend of permanganate index in Qinghai Lake from 2010 to 2020 

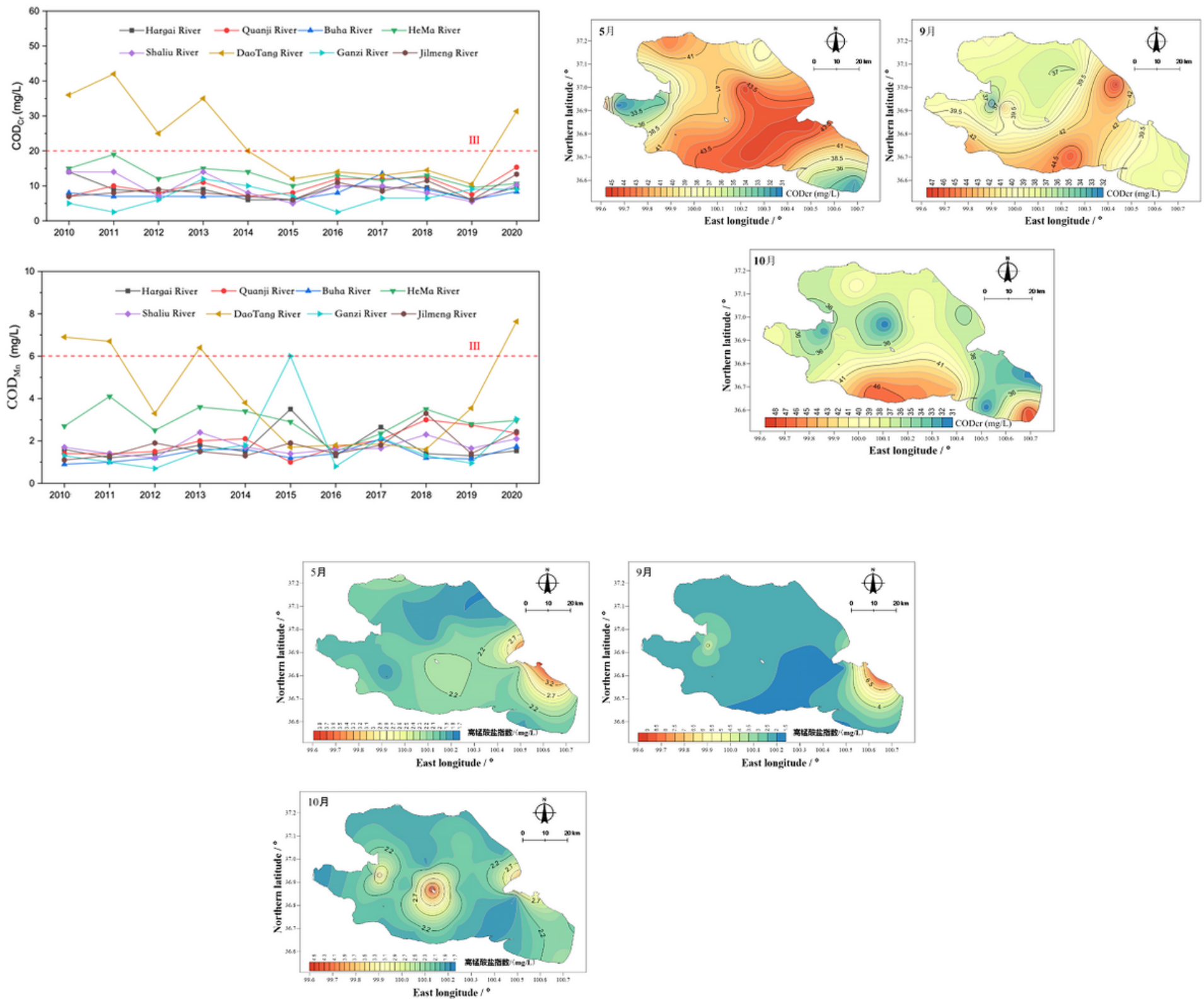

\section{Figure 4}

Change trend of CODCr in water body of rivers entering the lake from 2010 to 2020 Change trend of permanganate index of rivers entering the lake from 2010 to 2020 Spatial distribution characteristics of CODCr concentration in Qinghai Lake in different seasons Spatial distribution characteristics of permanganate index concentration in Qinghai Lake in different seasons 

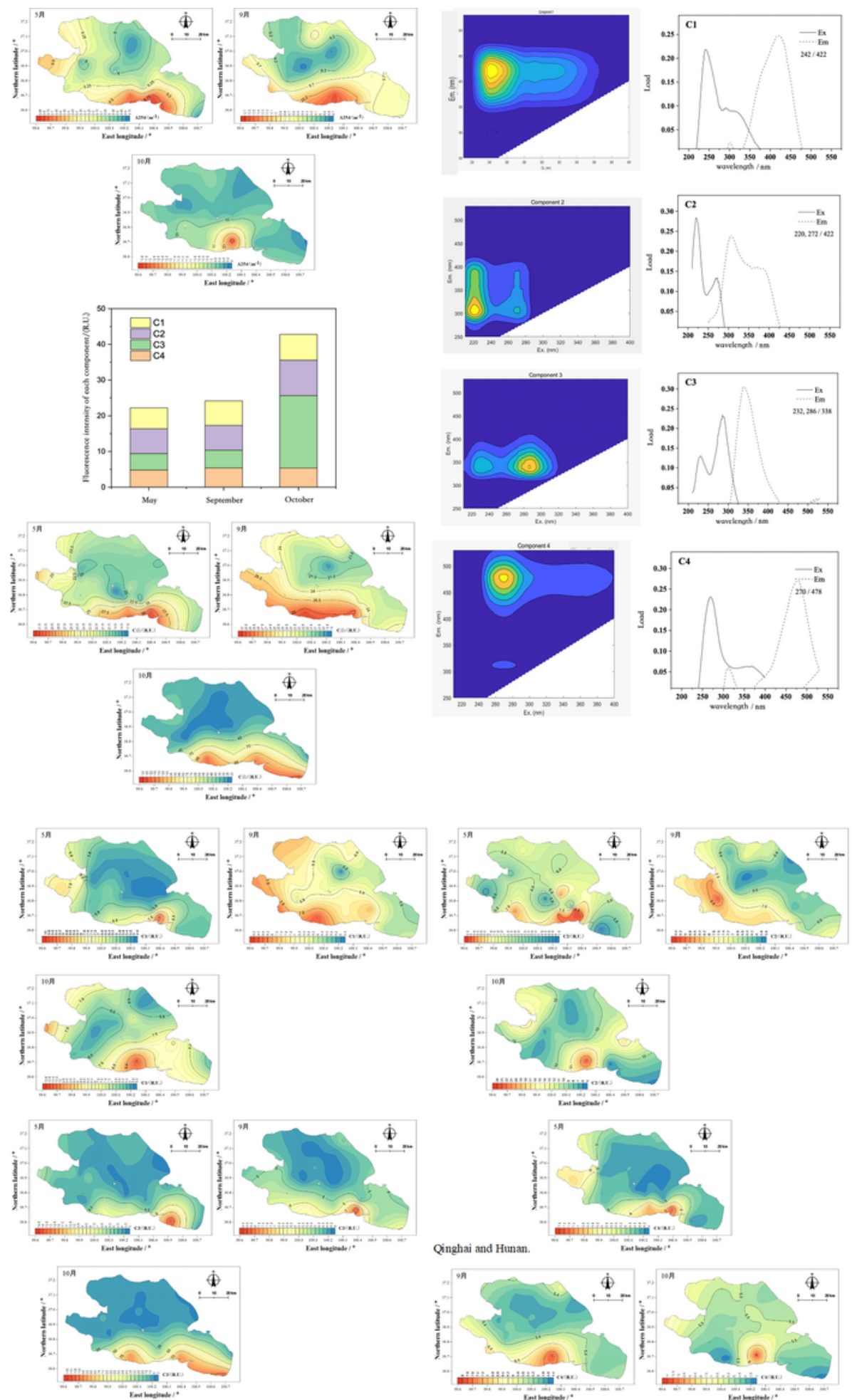

\section{Figure 5}

spatial distribution characteristics of CDOM concentration (a254, m-1) in water body of Qinghai Lake in different seasons characteristics of DOM fluorescence components in Qinghai Lake fluorescence intensity characteristics of DOM components in Qinghai Lake spatial distribution of total fluorescence intensity of FDOM in Qinghai Lake in different seasons spatial distribution characteristics of C1 fluorescence intensity in Qinghai lake water in different seasons spatial distribution characteristics of C2 
fluorescence intensity in Qinghai lake water in different seasons spatial distribution characteristics of C3 fluorescence intensity in Qinghai lake water in different seasons spatial distribution characteristics of C4 fluorescence intensity in Qinghai lake water in different seasons

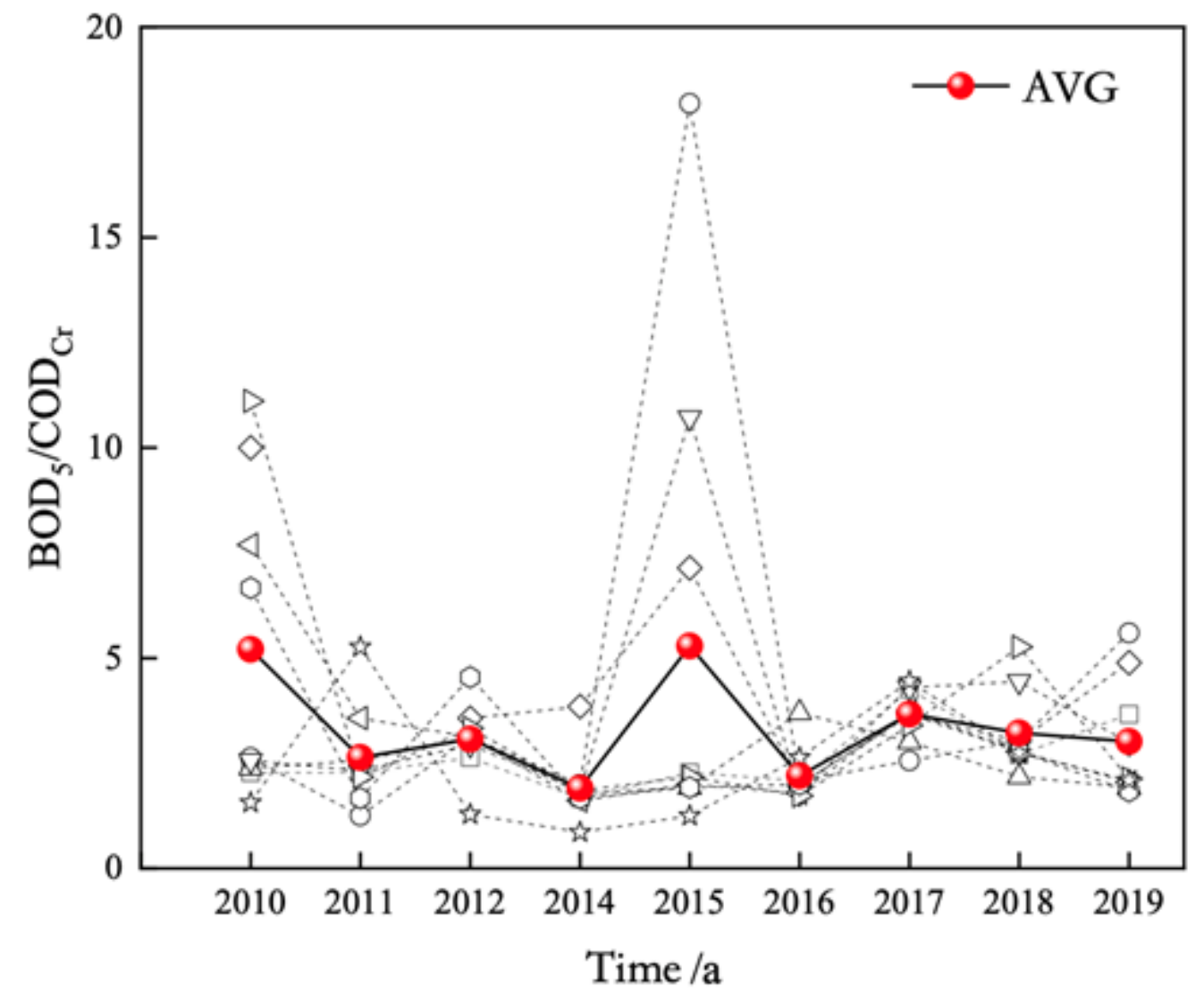

Figure 6

Bioavailability of DOM in Qinghai Lake 